resenha

\title{
Um apelo à prudência: conhecer e superar a marginalidade transcendendo as dualidades
}

Eliane Tassi dos Santos

Professora da rede municipal de Vinhedo

Saviani, Dermeval. Escola e democracia. 31 ed. Campinas: Autores Associados, 1997.

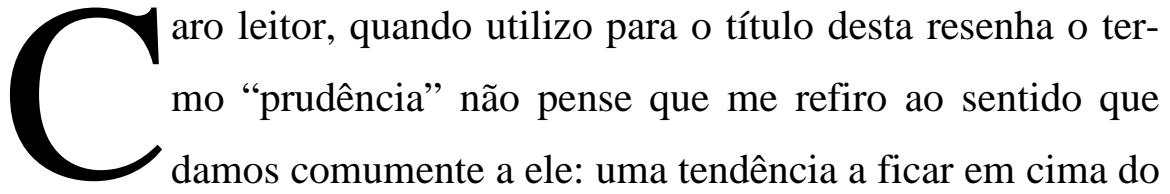
muro e não nos envolvermos com os problemas e resoluções dos mesmos. Ao contrário disso, quero fazer uso do seu sentido essencial, conforme defendido por Thomaz de Aquino: conhecer, se posicionar e tomar atitude. Pois, acredito que a intenção do autor, Prof. Dr. Dermeval Saviani, ao escrever o livro Escola e Democracia, de cuja resenha se ocupa este trabalho, fosse realmente que, ao fim da leitura, o leitor tivesse subsídios para se posicionar e tomar alguma atitude frente ao problema da marginalidade, o tema central dessa obra.

Outra questão que acredito ser necessário esclarecer desde o inicio é quanto ao termo marginalidade. Este termo, na referida obra, não tem relação com o sentido que o senso comum dispensa a ele: "bandidos" e "criminosos". O autor se refere aos que estão à margem da sociedade, num contexto educacional; aos que estão marginalizados da escola.

Esclarecidas estas questões, saiba, querido leitor, que o livro resenhado trata de questões cujo conhecimento e entendimento são essenciais ao profissional da educação que almeja desenvolver uma prática educativa de maneira séria e comprometida com sua sociedade. E, apesar de tratar de assuntos relevantes e de maneira profunda, traz uma linguagem clara e acessível a todos que possam se interessar pelo assunto. Mas é necessário que se faça a leitura com verdadeira vontade de enxergar verdades que possam estar veladas pelas ideologias que procuram nos envolver, ideologias essas que podem ter feito parte de toda a sua formação até então; assim como aconteceu comigo durante boa parte de minha vida. 
resenha

Prepare-se, então, para começar uma grande leitura, porque o autor discorre sobre os temas de forma que instiga-nos a ir além, página à página, mesmo após o fim do livro. Livro, aliás, que embora apresentado em um formato, relativamente, pequeno, por suas 40 edições podemos ter idéia, ao menos em parte, da grandeza e relevância de seu conteúdo e o domínio do autor sobre o tema abordado.

Claro que ao fim da leitura do livro você poderá discordar dessa resenha. Então, resenhe o livro novamente, partamos para o diálogo e busquemos transcender com prudência, pois, a minha começa agora:

Para iniciar, o autor explica a origem dos capítulos que se seguirão, esclarecendo que os três primeiros são artigos já publicados anteriormente e o último foi escrito especialmente para este livro. O que penso, tenha sido pelo imenso comprometimento que ele tem com sua consciência que acredita imprescindível lançar mão de cada oportunidade para contribuir com a desalienação política de seus leitores.

Já no primeiro capítulo ele faz uma explanação histórica das teorias da educação frente à marginalidade, dividindo-as em dois grupos:

- Teorias não-críticas: em que a educação é apresentada como um instrumento de equalização social e superação da Marginalidade.

- Teorias crítico-reprodutivistas: para as quais a educação é um instrumento de discriminação social e fator de marginalização.

O autor denomina o primeiro grupo de teorias não-críticas "porque desconhecem as determinações sociais do fenômeno educativo" (p. 27) e as subdivide em:

- "Pedagogia Tradicional": que surgiu para consolidar a democracia burguesa e para que a mesma vencesse a barreira da ignorância, para a qual os marginalizados são os ignorantes e "a escola surge como um antídoto contra a ignorância” (p. 18);

- "Pedagogia Nova": teve origem a partir das críticas à anterior, e os marginalizados passam a ser os rejeitados;

- "Pedagogia Tecnicista": "advoga a reordenação do processo educativo de maneira a torná-lo objetivo e operacional” (p. 23); os marginalizados são agora os incompetentes, improdutivos e ineficientes. 
resenha

E o autor resume que para a pedagogia tradicional a questão central é aprender, para a nova é aprender a aprender e para a tecnicista é aprender a fazer.

A partir das denominações que dividem as teorias em grupos descritos no livro, ficará visível que relacionando-as com a realidade que nos cerca, infelizmente, não há como discordar das afirmações do autor.

Ao segundo grupo de teorias o autor chama de críticas porque admitem condicionantes sociais à educação, mas, reprodutivas porque consideram que a função da escola é apenas reproduzir a sociedade, e também as subdivide:

- "Teoria do sistema de ensino enquanto violência simbólica";

- "Teoria da escola enquanto aparelho ideológico do Estado";

- "Teoria da escola dualista".

Após ressaltar a ingenuidade do primeiro grupo e a visão de impotência do segundo, o autor coloca questionamentos sobre as possibilidades de uma mudança e de uma teoria crítica e revolucionária. E o faz demonstrando otimismo, porém, com muita seriedade e realismo.

No segundo capítulo é explanado sobre três teses:

- Do caráter revolucionário da pedagogia da essência e do caráter reacionário da pedagogia da existência;

- Do caráter científico do método tradicional e do caráter pseudocientífico dos métodos novos;

- "Quando mais se falou em democracia no interior da escola menos democrática ela foi; e de como, quando menos se falou em democracia, mais articulada com a construção de uma ordem democrática" (p. 48).

Durante as explanações é possível enxergar as dualidades apontadas e não há como ficar imparcial frente a elas. Pois, quando o autor coloca, ao fim do capítulo, que crê ter conseguido fazer curvar a vara (referência que faz à teoria de Lênin), ele realmente o fez. Pois, se a intenção é justamente atingir a consciência do leitor que via, como o próprio autor cita, todas as virtudes na escola nova e todas as desventuras na escola tradicional, a esta altura é certo que o autor já obteve sucesso. Pois, ele coloca muito bem sua visão, historicamente comprovada, de como a burguesia se serviu da peda- 
resenha

gogia tradicional, com métodos científicos, na pedagogia da essência, e como, mais tarde, essa mesma burguesia muda seu discurso a favor da pedagogia nova com seus métodos pseudo-científicos na pedagogia da existência.

A partir daí o leitor irá entender a relação de escola e democracia e a terceira tese: quando muito se falava em democracia, na escola nova, ela não poderia existir porque os alunos não construíam bases para fazerem escolhas; já na escola tradicional, onde pouco se falava em democracia, oferecia-se aos alunos saberes necessários para escolhas e lutas futuras, imprescindíveis para o exercício da verdadeira democracia.

Caro leitor, a democracia de que se fala no livro está além dos muros da escola e, principalmente, após os anos de escolaridade fundamental.

Mas, conforme o autor continua no terceiro capítulo, sua visão é de que é necessário transcendermos todas as dualidades ditas até agora: Teorias não-críticas $\boldsymbol{x}$ Teorias crítico-reprodutivas; Pedagogia tradicional $\boldsymbol{x}$ Pedagogia nova; Pedagogias da essência $\boldsymbol{x}$ Pedagogias da Existência, e conforme ele discorre neste capítulo, conseguirmos vencer o embate Pedagogia Reacionária $x$ Pedagogia Revolucionária, claro, a favor da última.

No último capítulo o autor fala de onze teses sobre educação e política. Ele nos coloca como e porque educação e política são distintas, porém, inseparáveis.

$\mathrm{E}$, de tudo que este capítulo pode nos acrescentar, o que mais me marca, e, acredito, incomoda nossa consciência e nos impulsiona à prudência, são as teses $\mathrm{n}^{\circ} 2$ - "Toda prática educativa contém inevitavelmente uma dimensão política" (p. 98) - e no 11: “A função política da educação se cumpre na medida em que ela se realiza enquanto prática especificamente pedagógica" (p. 100).

Espero, sinceramente, que os leitores também se sintam incomodados com as questões que são apontadas neste livro, pois, acredito que em vários momentos a intenção do autor também foi nos incomodar e nos levar a questionar nossos conhecimentos e nossas visões de mundo, homem e educação até então. 